\title{
Oxygen reduction Kinetics on Electrodeposited PtCo as a Model Catalyst for proton Exchange Membrane Fuel Cell Cathodes: stability as a Function of PtCo Composition
}

\author{
Kaushik Jayasayee \\ Van Anh T. Dam \\ Tiny Verhoeven \\ Serdar Celebi
}

Frank A. de Bruijn

December 2009

ECN-W--09-052

Published in J. Phys.Chem. C 2009, 113, 20317 - 20380 



\title{
Oxygen Reduction Kinetics on Electrodeposited PtCo as a Model Catalyst for Proton Exchange Membrane Fuel Cell Cathodes: Stability as a Function of PtCo Composition
}

\author{
Kaushik Jayasayee, ${ }^{\dagger}$ Van Anh T. Dam, ${ }^{\dagger}$ Tiny Verhoeven, ${ }^{\dagger}$ Serdar Celebi, ${ }^{\dagger}$ and \\ Frank A. de Bruijn*,t,; \\ Inorganic Chemistry and Catalysis Group, Eindhoven University of Technology, $5600 \mathrm{MB}$ Eindhoven, The \\ Netherlands, and Energy Research Centre of The Netherlands (ECN), 1755 ZG, Petten, The Netherlands
}

Received: May 21, 2009; Revised Manuscript Received: October 16, 2009

\begin{abstract}
PtCo catalysts with composition varying between $\mathrm{Pt}_{80} \mathrm{Co}_{20}$ and $\mathrm{Pt}_{10} \mathrm{Co}_{90}$ were prepared by electrochemical underpotential codeposition. The bimetallic catalysts were subjected to 1000 electrochemical cycles in $0.5 \mathrm{M}$ $\mathrm{HClO}_{4}$ at room temperature. The activity and stability of these electrodes for oxygen reduction was determined, in conjunction with the characterization of these catalysts with energy dispersive X-ray spectroscopy, X-ray photoelectron spectroscopy, and transmission electron microscopy. Although Pt-rich electrodes had better activity in the initial stages of potential cycling, higher Co atomic ratios led to higher stability and higher oxygen reduction reaction (ORR) activity after electrochemical cycling. $\mathrm{Pt}_{10} \mathrm{Co}_{90}$ turned out to be the best electrode among the alloys considered, in terms of ORR activity and stability, which is linked to a higher concentration of Co on the surface.
\end{abstract}

\section{Introduction}

The technical status of the proton exchange membrane fuel cell PEMFC today is such that it can be successfully applied in vehicles, micro combined heat and power (micro-CHP) systems as well as portable applications, offering relatively high conversion efficiency without harmful emissions. Major hurdles that hinder mass market introduction are cost and durability, especially for its application in transport. When the focus is at reducing cost and improving durability, the PEMFC cathode deserves special attention.' Especially when clean hydrogen is used as fuel, the platinum loading at the cathode is the highest, while at the same time most degradation mechanisms take place at the cathode, such as platinum dissolution, particle growth, and carbon corrosion. ${ }^{2}$ In addition, operating the fuel cell at higher voltages for the sake of improving the cell efficiency is only viable when alternative catalysts are found that are able to reduce oxygen at a lower overpotential. ${ }^{3}$

Alloying $\mathrm{Pt}$ with transition metals such as $\mathrm{Co}, \mathrm{Ni}, \mathrm{Cr}, \mathrm{Mn}$, and $\mathrm{Fe}$ has proved to be a better alternative for supported $\mathrm{Pt}$ catalysts in terms of electrocatalytic activity and cost. ${ }^{4-7}$ Mukerjee et al. investigated various $\mathrm{Pt}$ bimetallic alloys supported on carbon and found a 2-3 fold increase in the oxygen reduction reaction (ORR) activity for the alloy catalysts under PEMFC operating conditions. ${ }^{8}$

PtCo bimetallic catalysts have been studied exhaustively during the past decade as it is one of the most promising catalytic composition for oxygen reduction. It was reported that Pt alloyed with Co on a carbon support yields better catalytic activity than pure $\mathrm{Pt}$, where $\mathrm{Pt}$ :Co ratios of $1: 1$ to $3: 1$ are most studied. ${ }^{3,9-11}$ Few reasons for the high catalytic activity for these alloys are ascribed to the modification of the electronic structure of Pt on alloying with Co and the "structural effect" on Pt even though the exact cause is still unclear. ${ }^{8,12}$ Non-noble metal rich alloy catalysts with a Pt monolayer/skin on the surface or Pt-enriched

\footnotetext{
* To whom correspondence should be addressed. E-mail: debruijn@ecn.nl.

${ }^{\dagger}$ Eindhoven University of Technology.

${ }^{\ddagger}$ Energy Research Centre of The Netherlands $(\mathrm{ECN})$.
}

nanoparticles shell with a bimetallic core are gaining interest nowadays owing to their unusually high catalytic activity with less Pt content. ${ }^{6,13-16}$ Very recently, a study has been published in which alloy catalysts with a wide variety of Pt:Co of 9:1 to 1:9 compositions were electrodeposited on a carbon sublayer and tested for their activity in a PEMFC. ${ }^{17}$ Catalysts with a high Pt content were shown to be the most active in this report.

To succeed commercially as an alternative for supported $\mathrm{Pt}$ catalysts, the stability of these alloy catalysts has to be examined without bringing down the performance. One of the difficulties in drawing ultimate conclusions is the complex structure introduced in the form of catalyst support in the system being investigated. It was reported that the Pt ORR activity depends on the method of preparation, the microstructure, particle size, and shape. ${ }^{18,19}$ Indeed, model catalysts are often employed to reduce this complex nature of the system and to study the catalytic behavior and the interactions between the metal particles exclusively. ${ }^{6}$

The aim of the present work is to deposit unsupported PtCo bimetallic alloys with various $\mathrm{Pt}$ :Co ratios through electrodeposition and study the ORR kinetics and stability of alloys in comparison to pure Pt prepared with the same procedure. The alloy electrodes were stressed through many potential cycles, and the ORR kinetics and the change in the Pt:Co ratio was investigated at regular intervals using energy dispersive $\mathrm{X}$-ray spectroscopy (EDS) and X-ray photoelectron spectroscopy (XPS).

\section{Experimental Section}

2.1. Electrode Preparation. PtCo alloys were deposited on a homemade $7 \mathrm{~mm}$ diameter Au rotating disk electrode (RDE) by underpotential electrochemical codeposition of $\mathrm{Pt}$ and $\mathrm{Co}$ following the procedure as described by Mallett et al. ${ }^{20}$ Using this method, the Pt:Co ratio can be tuned by changing the deposition potential in the range of $0-100$ atom \% of Co. The polished Au substrate was cleaned electrochemically in $0.5 \mathrm{M}$ $\mathrm{H}_{2} \mathrm{SO}_{4}$ by scanning between 0 and $1.7 \mathrm{~V}$ vs reversible hydrogen electrode (RHE). The catalyst layers were then grown from a 
solution consisting of $25 \mathrm{~g} / \mathrm{L}$ cobalt chloride, $1.5 \mathrm{~g} / \mathrm{L}$ chloroplatinic acid, and $30 \mathrm{~g} / \mathrm{L}$ sodium chloride. The $\mathrm{pH}$ of the electrolyte was maintained at 2.5 at $20^{\circ} \mathrm{C}$ by the addition of $\mathrm{HCl}$ and $\mathrm{NaOH}$. Pt thin films were also prepared using the same procedure but without cobalt chloride for comparison with $\mathrm{PtCo}$ alloys. The three-electrode cell used for electrodeposition consists of a platinized Pt foil as the counter electrode and a saturated calomel electrode (SCE) as the reference electrode.

The electrolytic bath was completely saturated with argon to remove the dissolved oxygen before the deposition of the catalysts. Galvanostatic electrochemical codeposition of $\mathrm{PtCo}$ thin films was carried out with current densities varying between 280 and $1000 \mathrm{uA} / \mathrm{cm}^{2}$ depending on the desired composition of Pt and $\mathrm{Co}$; the deposition time was fixed constant at $550 \mathrm{~s}$. This method resulted from a separate study, aimed at the reproducible deposition of PtCo electrodes. Galvanostatic deposition was found to yield a higher reproducibility than potentiostatic deposition. At the same time, galvanostatic deposition during a predetermined period leads to a constant electrode thickness at a given PtCo composition. An experimentally established relation between deposition current density and deposition potential allowed the tuning of the $\mathrm{Pt}: \mathrm{Co}$ composition by setting the deposition current density. This relation is shown in the Results section.

2.2. Electrochemical Characterization. Cyclic voltammograms (CVs) of the alloys were recorded at room temperature between $20 \mathrm{mV}$ and $1.3 \mathrm{~V}$ vs RHE at a scan rate of $50 \mathrm{mVs}^{-1}$ under Ar atmosphere. The ORR kinetics of the deposited alloys were studied at room temperature through hydrodynamic voltammetric measurements by employing a rotary system in the potential range of $200 \mathrm{mV}$ to $1.1 \mathrm{~V}$ vs RHE in the positive direction with a scan rate of $5 \mathrm{mVs}^{-1}$. The electrochemical cell was flushed with $\mathrm{O}_{2}$ for $45 \mathrm{~min}$ before the experiment, and the flow was maintained during the course of experiments to obtain an $\mathrm{O}_{2}$ saturated solution. The rotation speed of the disk electrode for each ORR experiment was $1000 \mathrm{rpm}$. While the limiting current is depending on the rotation speed of the disk electrode, it was determined that, in the current range of interest, where the current is not inffuenced significantly by diffusion, higher rotation speeds had no influence on the current measured. Both the $\mathrm{CV}$ and $\mathrm{RDE}$ experiments were conducted in $0.5 \mathrm{M} \mathrm{HClO}_{4}$, where a SCE was used as the reference electrode and a Pt foil was used as the counter electrode.

The half-wave potential $E_{1 / 2}$, the potential at which the current is $50 \%$ of the limiting current, is used as a measure for the overpotential for oxygen reduction on a particular electrode.

2.3. Stability Studies. The electrodeposited bimetallic electrodes were subjected up to 1000 electrochemical potential cycles to examine the stability in terms of real platinum surface area, ORR kinetics, and the change in the composition of $\mathrm{Pt}$ and $\mathrm{Co}$ in the electrode. The potential cycling was interrupted in between to record the $\mathrm{CV}$ and $\mathrm{RDE}$ voltammograms. $\mathrm{CV}$ and RDE voltammograms of all the catalysts were recorded after $1,15,65$, and 1000 potential cycles. The real surface area of active $\mathrm{Pt}$ was calculated for all the samples from the recorded CVs. The real surface area of the catalysts was determined by calculating the total charge under the hydrogen desorption region in the $\mathrm{CV}$, using $210 \mu \mathrm{C} \mathrm{cm}^{-2}$. The elemental composition of all the electrodes after each $\mathrm{CV}$ and RDE experiments were measured with EDS. All the potential cycling experiments were carried out at room temperature and ambient pressure.

2.4. Elemental Analysis. $\mathrm{Pt}$ and $\mathrm{Co}$ atomic percentages of all the alloy catalysts were determined by EDS and XPS.
The bulk compositions of all the electrodes were determined with a scanning electron microscopy (SEM) Philips XL-30-FEG (field emission gun) equipped with EDS. This EDS has a Si (Li) detector which is cooled by liquid nitrogen. The detector was positioned a few millimeters away from the surface of the sample to be analyzed. At least six different individual spots were focused and measured for their composition on every sample. It was found that the Pt and Co were homogeneously distributed over all the particles taken for measurement with a maximum of $1 \%$ error.

High-resolution elemental analysis on the surface of the catalysts was performed by applying XPS. The XPS measurements were carried out on a Kratos AXIS Ultra, equipped with

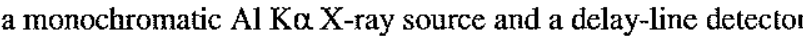
(DLD). Spectra were obtained using the aluminum anode (Al $\mathrm{K} \alpha=1486.6 \mathrm{eV}$ ) operating at $150 \mathrm{~W}$, with survey scans at a constant pass energy of $160 \mathrm{eV}$ and with region scans at a constant pass energy of $40 \mathrm{eV}$. The surface of the catalysts were etched for a few seconds with in situ ion beam sputtering using purified argon to remove the surface impurities. During sputtering, the sample was rotated, the pressure was increased to 3 $\times 10^{-8}$ mbar Argon, while the emission current was set to 15 $\mathrm{mA}$ with beam energy of $4 \mathrm{kV}$. For a limited number of compositions, the elemental composition was examined as a function of the sample depth by applying in situ XPS ion beam sputtering. In this method, the surface was sputtered to remove subsequent layers, followed by the characterization of the resulting surface. This sputtering and elemental analysis steps were carried out several times to get the elemental depth profile, in order to examine the homogeneity of the catalyst layer in terms of Pt:Co composition, before and after the electrochemical cycling.

2.5. Particle Size Analysis by Transmission Electron Microscopy (TEM). The effect of particle size on the ORR activity for selected catalysts before and after potential cycling was analyzed by TEM. The catalysts were scratched from the Au substrate, dispersed in ethanol, and grounded well. The dispersed particles were then mounted on a carbon-coated $\mathrm{Cu}$ grid (200 mesh) and dried at room temperature to remove the ethanol. A Technai-Sphera microscope with a voltage of 200 $\mathrm{kV}$ was used to analyze the particle size of $\mathrm{Pt}, \mathrm{Pt}_{75} \mathrm{CO}_{25}$, and $\mathrm{Pt}_{10} \mathrm{Co}_{90}$ before and after 1000 potential cycles.

\section{Results and Discussion}

3.1. Characterization of Fresh Catalysts. As described in the experimental section, electrodes could be deposited most reproducibly by galvanostatic deposition. Figure 1 shows the relation between the deposition current density and the resulting deposition potential. As can be seen from Figure 1b, the deposition potential was almost constant during the PtCo composition.

EDS analysis for the bulk electrode and XPS analysis for the surface of the electrode under various PtCo deposition potentials is shown in Figure 2. From the XPS data, for $\mathrm{Pt}_{75} \mathrm{CO}_{25}$ and $\mathrm{Pt}_{10} \mathrm{CO}_{90}$, the average composition of $\mathrm{Pt}$ and $\mathrm{Co}$ over the depth of the catalyst layer was used for comparison. For other catalysts, only the surface Pt and Co composition was taken, as no depth profile was made for these catalysts. The elemental compositions measured using these techniques were highly comparable with very minimum difference. Figure 3 shows the depth profile of freshly deposited $\mathrm{Pt}_{75} \mathrm{CO}_{25}$ catalyst. It was found that the distribution of $\mathrm{Pt}$ and $\mathrm{Co}$ was homogeneous throughout the bulk of the catalyst with a very slight Pt enrichment on the top surface layer, as long as the Au substrate was fully covered by electrodeposited PtCo. 

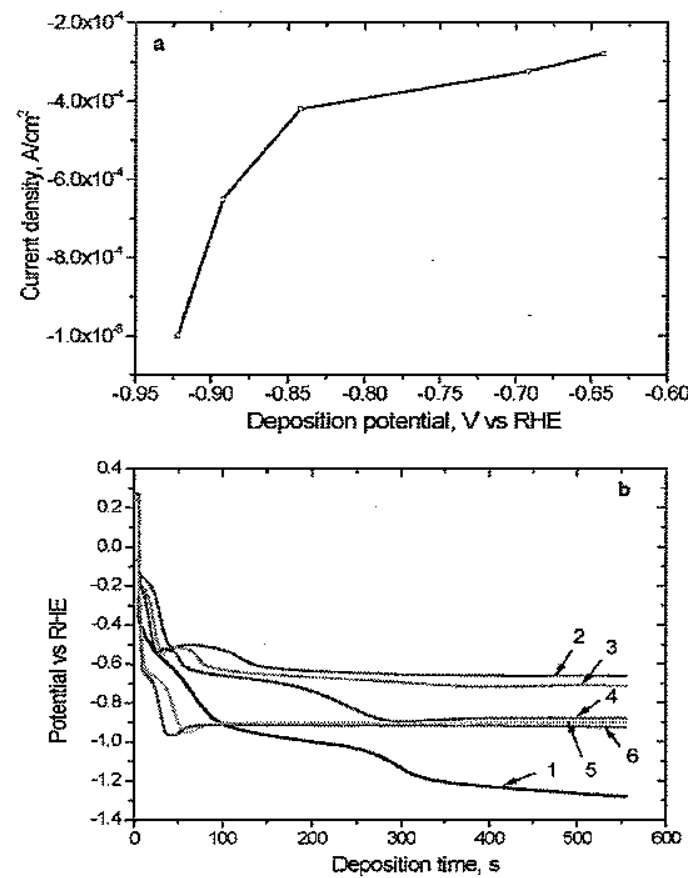

Figure 1. (a) Relation between current density and deposition potential. (b) Pt:Co compositions can be altered by galvanostatic deposition: 1-Pt $2-\mathrm{Pt}_{80} \mathrm{Co}_{20}, 3 \mathrm{Pt}_{75} \mathrm{Co}_{25}, 4-\mathrm{Pt}_{60} \mathrm{Co}_{40}, 5-\mathrm{Pt}_{30} \mathrm{Co}_{70}, 6-\mathrm{Pt}_{10} \mathrm{C}_{90}$.

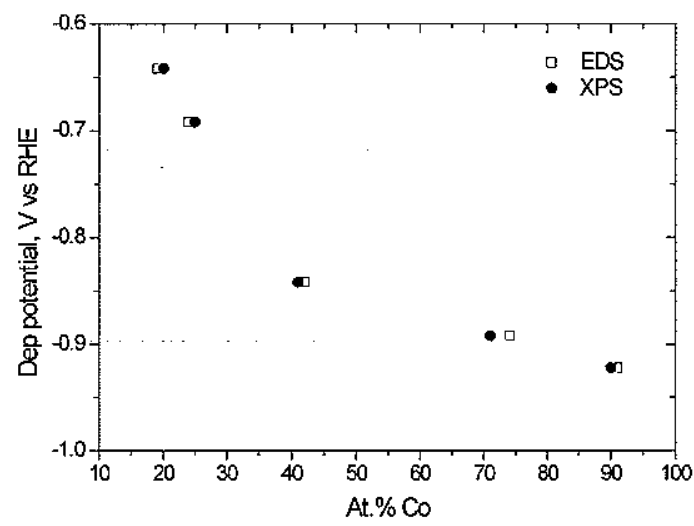

Figure 2. Elemental compositions of freshly deposited $\mathrm{Pt}$ and $\mathrm{PtCo}$ bimetallic alloys analyzed with EDS and XPS.

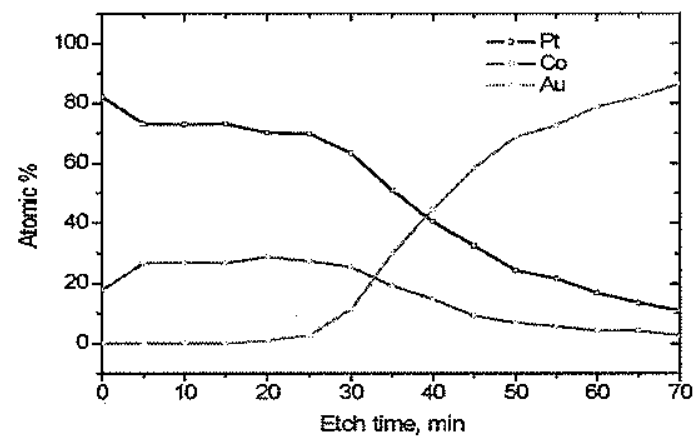

Figure 3. XPS depth profile of fresh $\mathrm{Pt}_{75} \mathrm{Co}_{25}$ deposited on Au.

Typical CVs of $\mathrm{Pt}, \mathrm{Pt}_{80} \mathrm{Co}_{20}, \mathrm{Pt}_{75} \mathrm{Co}_{25}, \mathrm{Pt}_{60} \mathrm{Co}_{40}$, and $\mathrm{Pt}_{30} \mathrm{Co}_{70}$ catalysts immediately after preparation are shown in Figure 4. The potential range between 20 and $400 \mathrm{mV}$ in both forward and reverse scans reveals that these Pt-based alloy catalysts have a comparable hydrogen adsorption/desorption charge, irrespective of the Pt:Co ratio. The oxide reduction peak does, however, vary significantly with the Co composition without a clear

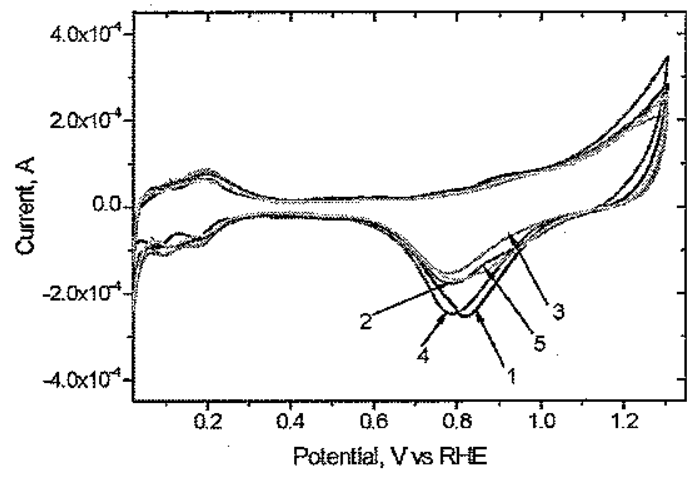

Figure 4. CVs of fresh Pt and PtCo alloys. Conditions: $50 \mathrm{mV} / \mathrm{s}, 20$ ${ }^{\circ} \mathrm{C}, 0.5 \mathrm{M} \mathrm{HClO}_{4} ; 1-\mathrm{Pt}, 2-\mathrm{Pt}_{80} \mathrm{Co}_{20}, 3-\mathrm{Pt}_{75} \mathrm{Co}_{25}, 4-\mathrm{Pt}_{60} \mathrm{Co}_{40}, 5-\mathrm{Pt}_{30} \mathrm{CO}_{70}$.

relation between the alloy composition and the size of the $\mathrm{Pt}$ oxide reduction peak. The leaching of Co from the catalyst surface during the first electrochemical cycle leads to a welldefined Pt surface even for Co-rich catalysts.

$\mathrm{Pt}_{10} \mathrm{Co}_{90}$ appeared to show a marked difference between the first and the second scan as shown in Figure $5 \mathrm{a} . \mathrm{Pt}_{10} \mathrm{Co}_{90}$ has two very distinct peaks, one at 650 and the other at $950 \mathrm{mV}$ at the anodic sweep of first $\mathrm{CV}$ which was not observed for other compositions. These peaks correspond to the dissolution of excess Co compounds from the as-prepared surface of the catalyst. The area under the $H_{\text {UPD }}$ of both cycle 1 and cycle 2 corresponds to a platinum surface area, which is even higher than which is present in all other Pt:Co alloy compositions. The dissolution of Co from the surface during the first $\mathrm{CV}$ does not expose any additional Pt to the surface, which was evident from the presence of similar hydrogen oxidation region in the anodic portion of both the CVs. The Co dissolution peaks disappeared during the second $\mathrm{CV}$, and the profile resembles that of the pure Pt surface. The presence of excess Co on the fresh electrodeposited surface of $\mathrm{Pt}_{10} \mathrm{CO}_{90}$ was supported by the XPS depth profile study on the sample as shown in Figure $5 \mathrm{~b}$. The surface of the as-prepared catalyst consists of nearly $97 \%$ cobalt. Upon sputtering, the amount of Co tends to decrease from 97 atom $\%$ to around 90 atom $\%$ and then the bimetallic atomic composition remains homogeneously dispersed. These observations lead to the conclusion that, although $\mathrm{Co}$ is abundant in the fresh catalyst, it does not cover the Pt particles, as Co oxidation and dissolution does not lead to an increase in platinum surface area.

3.2. ORR Kinetics. 3.2.1. Fresh Catalysts. RDE studies were carried out to obtain ORR kinetics for various PtCo compositions. Figure 6a shows the anodic sweeps of all the catalysts under oxygen atmosphere measured after 15 potential cycles. The ORR kinetic profile after $15 \mathrm{CVs}$ was taken, as this better represents a fresh fuel cell catalyst that has been in fuel cell operation for a short time, i.e., the effects of surface impurities and excess Cobalt being present after preparation are being excluded. Figure 6 a depicts a prominent reduction in the overpotential for the ORR by alloying Co with $\mathrm{Pt}$, as claimed by many researchers in terms of enhancement factors. ${ }^{5,9,10,22}$ Depending on the Co percentage, a reduction of around 50-200 $\mathrm{mV}$ in the overpotential was achieved for the ORR compared to pure Pt catalyst at the half-wave potential $E_{1 / 2}$. The results indicate that, during the initial cycling, the catalysts with ca. 25 and 20 atom \% Co have better electrocatalytic activities than the others. The exception is $\mathrm{Pt}_{10} \mathrm{CO}_{90}$, which shows the same and even better activity as that of $\mathrm{Pt}_{75} \mathrm{CO}_{25}$ and $\mathrm{Pt}_{80} \mathrm{Co}_{20}$, respectively. In contradiction to these observations, Saejeng et 

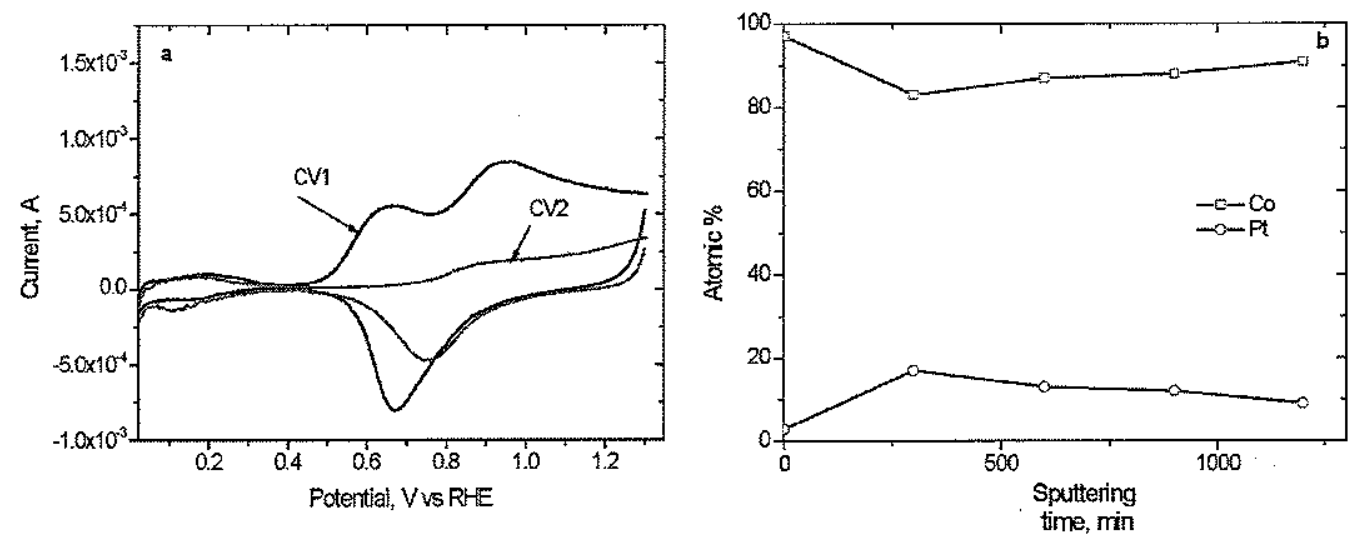

Figure 5. (a) $\mathrm{CVs}$ of $\mathrm{Pt}_{10} \mathrm{CO}_{90}$ after 1 and 2 potential cycles. Conditions: $50 \mathrm{mV} / \mathrm{s}, 20{ }^{\circ} \mathrm{C}, 0.5 \mathrm{M} \mathrm{HClO}_{4}$. (b) XPS depth profile of fresh $\mathrm{Pt}_{10} \mathrm{Cog}_{90}$ deposited on $\mathrm{Au}$.
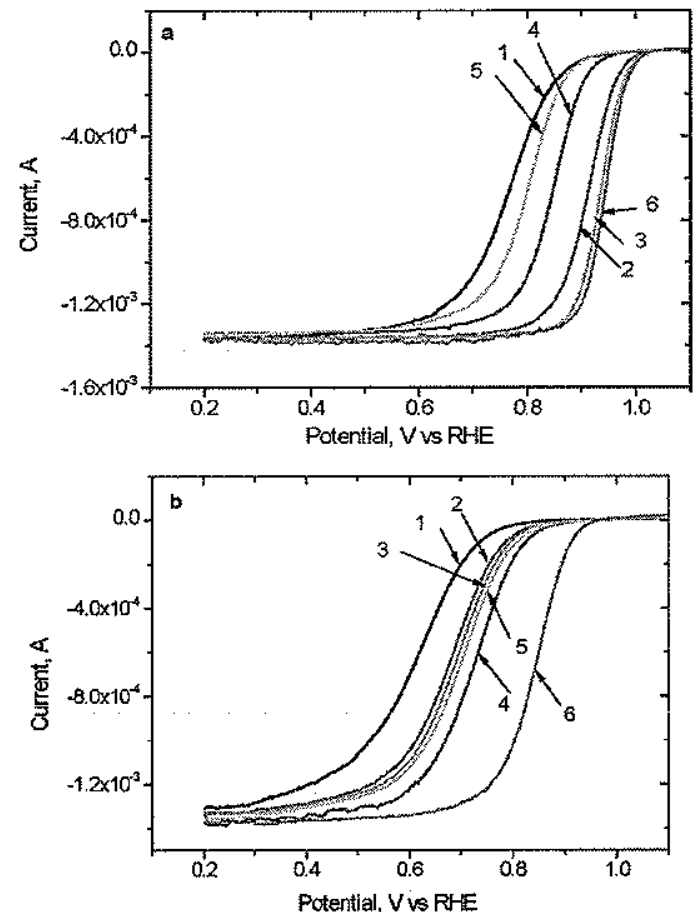

Figure 6. Potentiodynamic voltammograms of $\mathrm{Pt}$ and $\mathrm{PtCo}$ alloys after (a) $15 \mathrm{CVs}$ (b) after $1000 \mathrm{CVs}$. Conditions: $5 \mathrm{mV} / \mathrm{s}, 20^{\circ} \mathrm{C}$, oxygen saturated $0.5 \mathrm{M} \mathrm{HClO}_{4}, 1000 \mathrm{rpm} ; 1=\mathrm{Pt}, 2=\mathrm{Pt}_{80} \mathrm{Co}_{20}, 3=\mathrm{Pt}_{75} \mathrm{Co}_{25}$, $4=\mathrm{Pt}_{60} \mathrm{Co}_{40}, 5=\mathrm{Pt}_{30} \mathrm{Co}_{70}, 6=\mathrm{Pt}_{10} \mathrm{CO}_{90}$

al. observed a very low performance for their electrodeposited Pt:Co alloy with 10:90 atomic ratio when used in the PEMFC cathode. ${ }^{17}$ The difference in the performance of these two studies can be attributed to the different electrodeposited procedures adopted and the introduction of support material. The observed contradiction emphasizes further the critical roles of catalyst preparation conditions and the support materials on the performance.

3.2.2. Influence of Cycling. Figure $6 \mathrm{~b}$ shows the oxygen reduction activity of all the catalysts as anodic sweeps under oxygen atmosphere measured after 1000 potential cycles.

It is a known that Co or any other non-noble metal alloyed with $\mathrm{Pt}$ will dissolve at a faster rate than $\mathrm{Pt}$ under fuel cell conditions. ${ }^{3,23}$ It is often reported that the dealloying of nonnoble metal might increase the ORR activity of bimetallic alloys. ${ }^{5,24}$ So it is very important to study the stability of alloying elements in the catalysts at regular intervals and equate them with their performance.
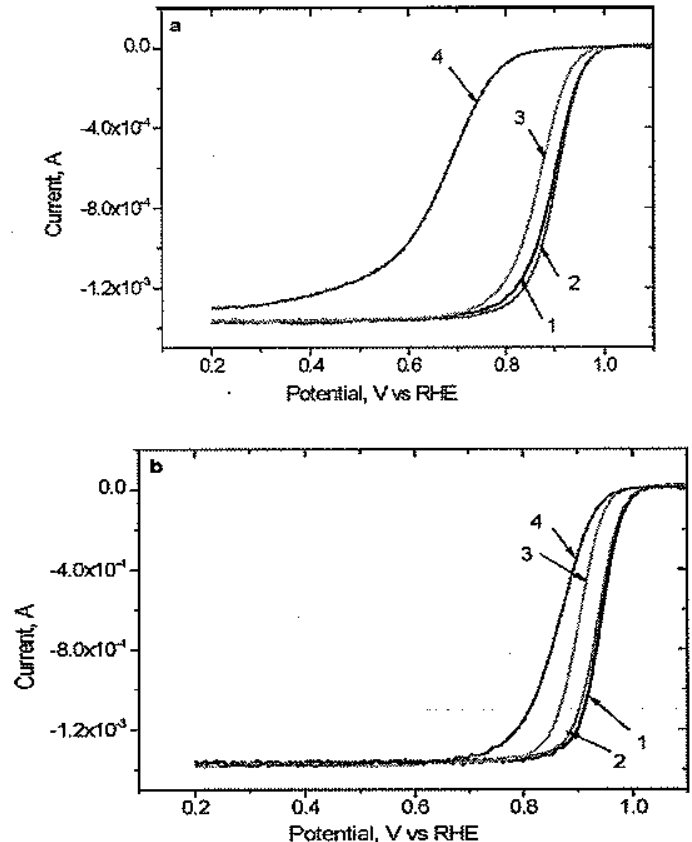

Figure 7. Potentiodynamic voltammograms of (a) $\mathrm{Pt}_{75} \mathrm{Co}_{25}$ and (b) $\mathrm{Pt}_{10} \mathrm{Co}_{90}$ during potential cycling. Conditions: $5 \mathrm{mV} / \mathrm{s}, 20^{\circ} \mathrm{C}$, oxygen saturated $0.5 \mathrm{M} \mathrm{HClO}_{4}, 1000 \mathrm{rpm} ; 1=1 \mathrm{CV}, 2=15 \mathrm{CVs}, 3=65$ $\mathrm{CVs}, 4=1000 \mathrm{CVs}$.

As can be concluded from comparing Figure $6 \mathrm{a}$ and $\mathrm{b}, \mathrm{Pt}$ rich bimetallic electrodes could not retain their initial higher ORR activity after 1000 potential cycles. Figure 7 compares the stability of $\mathrm{Pt}_{75} \mathrm{CO}_{25}$ with $\mathrm{Pt}_{10} \mathrm{Co}_{90}$ under cycling conditions. For $\mathrm{Pt}_{75} \mathrm{Co}_{25}$. Figure 7a, a negative shift of around $220 \mathrm{mV}$ is measured when comparing the half wave potential for oxygen reduction of a fresh electrode to that after 1000 cycles. While this shift is much higher than for pure platinum (135 mV), the oxygen reduction activity of $\mathrm{Pt}_{75} \mathrm{Co}_{25}$ after 1000 cycles is still higher than that of pure $\mathrm{Pt}$. Co rich bimetallic catalysts show greater stability after $1000 \mathrm{CVs}$ as the shift of the half wave potential is around $100 \mathrm{mV}$. The greater activity and stability shown by $\mathrm{Pt}_{10} \mathrm{Co}_{90}$ in Figure $7 \mathrm{~b}$ right from the initial cycles is interesting in both the research and economic point of view as the platinum content is very low while still offering a higher activity than all the other alloys. A comparable effect was reported by Strasser et al. for $\mathrm{Pt}_{25} \mathrm{Cu}_{75}$, which had a higher activity than other $\mathrm{Pt}$ rich bimetallic catalyst. ${ }^{25}$ The author reported about the formation of Pt-enriched nanoparticles shell and a $\mathrm{Cu}$ core by the leaching of $\mathrm{Cu}$ from the surface during 


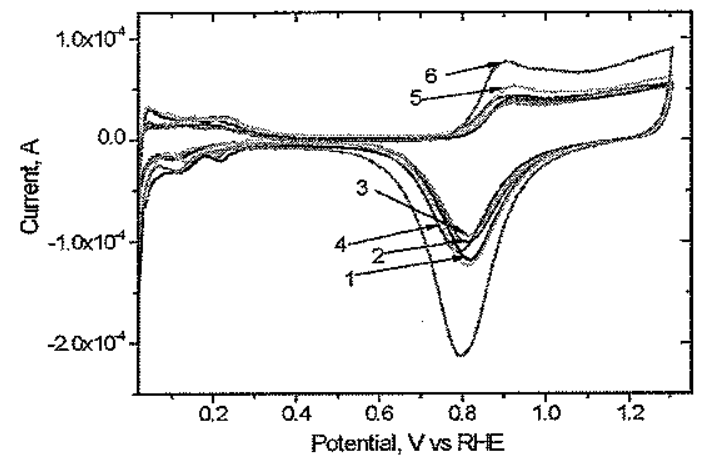

Figure 8. Cyclic voltammograms of Pt and PtCo alloys after 1000 CVs. Conditions: $50 \mathrm{mV} / \mathrm{s}, 20^{\circ} \mathrm{C}, 0.5 \mathrm{M} \mathrm{HClO}_{4} ; 1=\mathrm{Pt}, 2=\mathrm{Pt}_{80} \mathrm{Co}_{20}$ $3=\mathrm{Pt}_{75} \mathrm{Co}_{25}, 4=\mathrm{Pt}_{60} \mathrm{Co}_{40}, 5=\mathrm{Pt}_{30} \mathrm{Co}_{70}, 6=\mathrm{Pt}_{10} \mathrm{Co}_{90}$.

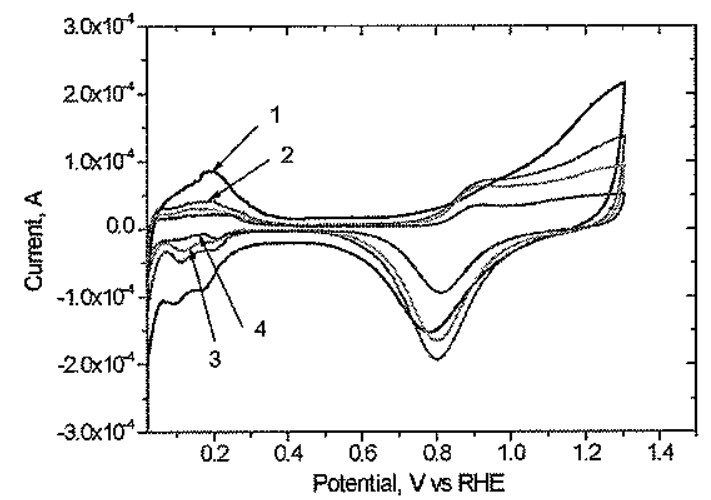

Figure 9. $\mathrm{CV}$ profiles of $\mathrm{Pt}_{75} \mathrm{CO}_{25}$ during potential cycling. Conditions: $50 \mathrm{mV} / \mathrm{s}, 20^{\circ} \mathrm{C}, 0.5 \mathrm{M} \mathrm{HClO}_{4} ; 1=1 \mathrm{CV}, 2=15 \mathrm{CVs}, 3=65 \mathrm{CVs}$ $4=1000 \mathrm{CVs}$.

potential cycling. The primary reason for the higher activity of dealloyed $\mathrm{Cu}$-rich $\mathrm{Pt}-\mathrm{Cu}$ nanoparticles was believed to be due to the modified geometric and electronic properties of the $\mathrm{Pt}$ enriched nanoparticles. Further studies such as surface composition analysis in the likes of formation of Pt skin monolayer or the Pt shell-Co core particle ensembles are needed.

3.3. Influence of Potential Cycling on Electrode Composition. 3.3.1. Cyclic Voltammetry and EDS. The CV profile of the bimetallic catalysts after 1000 potential cycles is shown in Figure 8. The striking difference between $\mathrm{Pt}_{10} \mathrm{CO}_{90}$ and all other compositions was the high $\mathrm{Pt}$ oxidation and $\mathrm{Pt}$ oxide reduction charge while the charge associated with hydrogen adsorption was lower than or equal to other samples. Connecting this to the exceptional activity of $\mathrm{Pt}_{10} \mathrm{CO}_{90}$ as noticed in Figures 4 and 5 , the high catalytic activity of $\mathrm{Pt}_{10} \mathrm{Co}_{90}$ might be linked to the enhanced oxygen adsorption on this composition in comparison to all the other compositions.

Figure 9 shows the change in $\mathrm{CV}$ profile of $\mathrm{Pt}_{75} \mathrm{CO}_{25}$ as the result of potential cycling. The electrochemical active surface area of Pt in the catalyst decreases with an increase in number of cycles which is attributed to the leaching of both platinum and cobalt from the catalyst particles from the surface of the catalyst as well as agglomeration of Pt particles and particle growth. The dissolution of platinum ions during the anodic sweep from the catalyst surface and redeposition on a different particle while reversing the potential would increase the particle size, the process of which is referred to as Ostwald ripening. However, cobalt, which is easily soluble in this environment, will not redeposit and hence does not contribute to the Ostwald ripening process. The CVs also expose the distinct appearance of the strong and weak $H_{\text {UPD }}$ peaks of Pt with potential cycling.

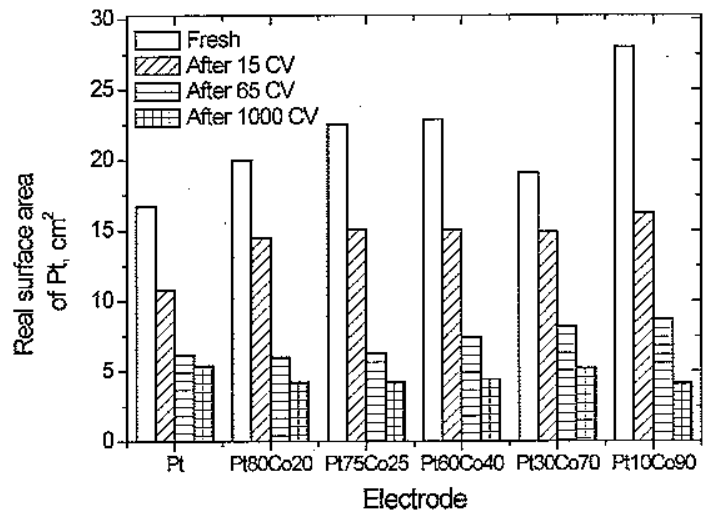

Figure 10. Available active $\mathrm{Pt}$ surface area of $\mathrm{Pt}$ and Pt:Co alloys during potential cycling.

This could be due to the complete dissolution of the non-noble alloying metal from the surface of the catalyst layer. Increasing the number of cycles shifts the platinum oxide reduction peak potential toward high potentials, thus suggesting an increase in the average particle size of $\mathrm{Pt}^{21}$

The active Pt surface area of all the electrodes calculated after respective potential cycles is shown in Figure 10. It can be seen that right from the first potential cycle, pure platinum electrodes show a lower surface area than the other bimetallic catalysts. The presence of traces of Co on the surface of other bimetallic catalysts which could block the adsorption of hydrogen atoms does not affect the effective surface area. After cycling up to 15 potential cycles, the active Pt surface area of all the catalysts decreases drastically. Pure Pt catalysts loose about half of their platinum active surface area after 15 cycles, and two-thirds after 65 cycles. The bimetallic catalysts lose only about $50 \%$ of their active Pt surface area after 65 cycles, irrespective of their compositions. The rapid dissolution of $\mathrm{Co}$ in the initial cycles does not have a direct influence in increasing the active $\mathrm{Pt}$ surface area. The active Pt surface area after 1000 potential cycles is comparable for all the electrodes.

Figure 11 shows the comparison between the oxygen reduction activity as given by the half wave potential $E_{1 / 2}$, and the elemental composition as determined by EDS. All the bimetallic catalysts loose their Co rapidly during the initial CV cycles. $\mathrm{Pt}_{80} \mathrm{Co}_{20}$ loses almost half of its original Co content after 15 $\mathrm{CVs}$, and the rest of the catalysts loose about 30 atom \% of their $\mathrm{Co}$. This initial selective dealloying of Co from the surface helps electrodes with high Co content to improve their activity or at least to keep their initial ORR activity after $15 \mathrm{CVs}$ (Figure 7 ), even while the platinum surface area decreases. The bimetallic catalysts other than $\mathrm{Pt}_{80} \mathrm{CO}_{20}$ (which lost about twothirds of $\mathrm{Co}$ ) lost almost 60 atom \% Co of initial composition after 65 cycles. $\mathrm{Pt}_{80} \mathrm{Co}_{20}$ has only 6 atom $\%$ Co left after 65 cycles, while $\mathrm{Pt}_{75} \mathrm{CO}_{25}$ has 11 atom \% after 65 cycles. This difference might help $\mathrm{Pt}_{75} \mathrm{CO}_{25}$ to have a half-wave potential, which is $30 \mathrm{mV}$ more positive, even though both catalysts had the same active Pt surface area. Interestingly, all the catalysts show a negative shift of 30-60 mV after $65 \mathrm{CVs}$ other than $\mathrm{Pt}_{30} \mathrm{CO}_{70}$, which shows a shift of only $5 \mathrm{mV}$; hence $\mathrm{Pt}_{30} \mathrm{CO}_{70}$ shows better stability for dynamic potential scans. After 1000 potential cycles, Pt-rich alloys end up with trace amounts of Co, while Co-rich alloys end up with a Co composition between 10 and 15 at $\%$. The consolidated amount of $\mathrm{Co}$ in these catalysts present after $1000 \mathrm{CVs}$ might explain their enhanced stability as shown in Figures 6 and 7.

3.4. XPS Depth Profiles. The XPS depth profile of $\mathrm{Pt}_{75} \mathrm{Co}_{25}$ and $\mathrm{Pt}_{10} \mathrm{CO}_{90}$ after $1000 \mathrm{CVs}$ was evaluated by the same 

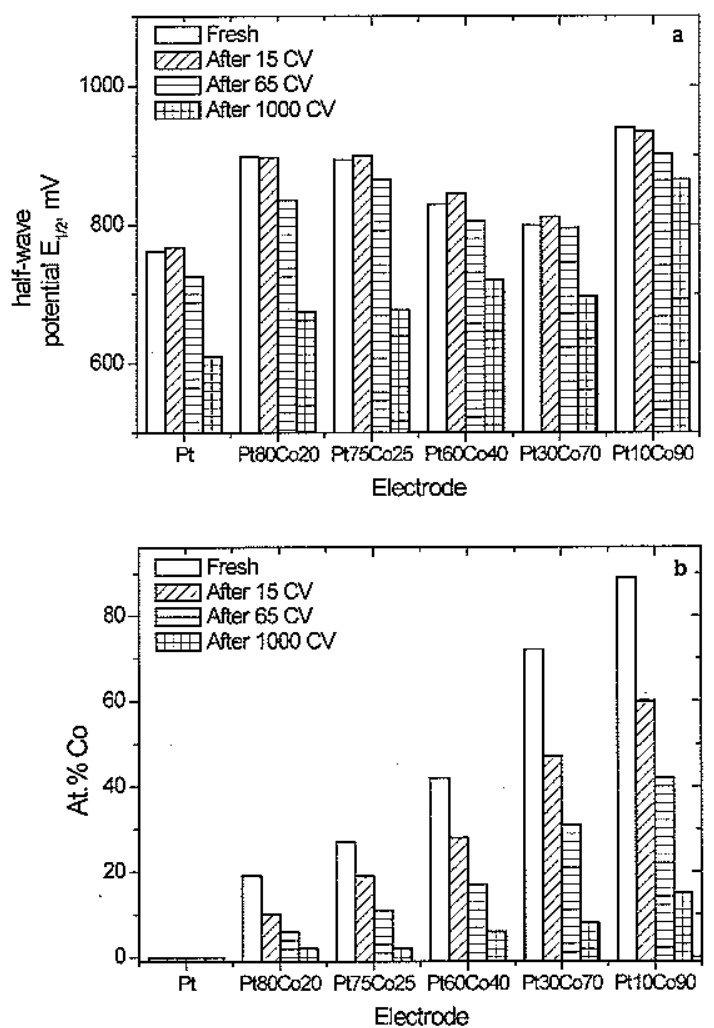

Figure 11. (a) Performance loss and (b) change in Pt:Co composition during potential cycling.

procedure as mentioned for the fresh electrodes. The absence of cobalt on the surface and from the underlying layers of $\mathrm{Pt}_{75} \mathrm{CO}_{25}$ is clearly observed in Figure 12a. But after $600 \mathrm{~s}$ of sputtering, exposing the core of the Pt:Co electrode, the amount of Co rises until an atomic ratio of $\mathrm{Pt}$ :Co of 3:1, as present in these electrodes before potential cycling, is reached. This substantiates the dissolution of $\mathrm{Co}$ from the bimetallic electrode surface during cycling, resulting in a Pt-rich layer. This Pt-rich layer in turn protects the Co from the bulk of the alloy from further dissolution. As there is no Co present in the subsurface layers after 1000 cycles, the electrode surface will have the properties that resemble that of pure platinum, with the concomitant decrease in oxygen reduction activity. The average amount of Co present in this electrode after dissolution studies was $\sim 9$ atom $\%$ and does not exactly match the result from EDS, which show only 2 atom $\%$.

The depth profile of $\mathrm{Pt}_{10} \mathrm{Co}_{90}$ shown in Figure $12 \mathrm{~b}$ was quite different to that of $\mathrm{Pt}_{75} \mathrm{Co}_{25}$ with respect to the Co content. $\mathrm{Pt}_{10} \mathrm{Co}_{90}$ still has a significant amount of Co left on the surface as compared to the bulk of the electrode. The amount of $\mathrm{Co}$ in the alloy tends to increase from 10 atom $\%$ on the surface to 35 atom \% as the sputtering continues toward the bulk of the electrode. This presence of $\mathrm{Co}$ on the surface of $\mathrm{Pt}_{10} \mathrm{Co}_{90}$ helps the alloy to retain its ORR activity and enhanced stability as compared to other bimetallic alloys considered. The average Co composition for this sample is almost comparable with that of the EDS, and the amount is 17 atom \% from XPS study and 15 atom \% from EDS analysis.

The core level spectrum of $\mathrm{Pt} 4 \mathrm{f}_{7 / 2}$ was used to estimate the shift in binding energy as a result of alloying with respect to pure platinum. Figures 13 and 14 and Table 1 summarize the binding energies computed by standard peak fittings for $\mathrm{Pt}$, Co metallic, and Co oxides from Co $2 p_{3 / 2}$ spectra for both fresh and cycled $\mathrm{Pt}_{75} \mathrm{CO}_{25}$ and $\mathrm{Pt}_{10} \mathrm{Co}_{90}$. Co $2 \mathrm{p}$ spectra acquired before and after sputtering the fresh $\mathrm{Pt}_{75} \mathrm{CO}_{25}$ and $\mathrm{Pt}_{10} \mathrm{Co}_{90}$ yielded a Co $2 \mathrm{p}_{3 / 2}$ spectrum that contained contributions of metallic cobalt, with a peak between 778.1 and $778.4 \mathrm{eV}$, as well as of oxidic cobalt, with a peak between 780.1 and $780.9 \mathrm{eV}$. The ratio of oxidized versus metallic cobalt was higher on the surface than it was after sputtering.

The shift in binding energy of $\mathrm{Pt} 4 \mathrm{f}_{7 / 2}$ for $\mathrm{Pt}$ after alloying with transition metals such as cobalt is interesting as it helps in correlating the change in the electronic structure of Pt visà-vis catalytic activity. ${ }^{18,26,27}$ The $\mathrm{Pt} 4 \mathrm{f}_{7 / 2}$ spectrum of fresh $\mathrm{Pt}_{75} \mathrm{Co}_{25}$ before sputtering shows a strong peak with a binding energy of $71.2 \mathrm{eV}$, which is representative of pure metallic platinum, thus suggesting $\mathrm{Pt}$ enrichment on the surface as shown in Figure 3. After sputtering, however, the peak position of $\mathrm{Pt} 4 \mathrm{f}_{7 / 2}$ is shifted to $71.6 \mathrm{eV}$, i.e., in the bulk of the catalyst, platinum has a higher interaction with cobalt than on the surface. As expected, the position of the $\mathrm{Pt} 4 \mathbf{f}_{7 / 2}$ core level spectrum of fresh $\mathrm{Pt}_{10} \mathrm{CO}_{90}$ shifts to an even higher binding energy of $71.8 \mathrm{eV}$ on both the surface and bulk of the electrode, indicating a strong electronic interaction of $\mathrm{Pt}$ and $\mathrm{Co}$. Cobalt being more electropositive than $\mathrm{Pt}$ will donate its electrons easily, and so the binding energy of Pt should shift toward lower binding energy. But here in the bulk of these alloys, a positive shift in the binding energy of $\mathrm{Pt} 4 \mathrm{f}_{7 / 2}$ for $\mathrm{Pt}$ is observed, hinting to a loss of electrons from platinum. Similar observations were reported by Wakisaka et al. ${ }^{26}$ for the unsupported $\mathrm{Pt}_{58} \mathrm{Co}_{42}$ alloy, by Duong et al. ${ }^{28}$ for a commercially available unsupported $\mathrm{Pt}_{3} \mathrm{Co}$ alloy, and by Toda et al. for $\mathrm{Pt}$ alloyed with $\mathrm{Co}, \mathrm{Ni}$ and $\mathrm{Fe}^{27}$ This kind of behavior was also confirmed by Mukerjee et al. with in situ X-ray absorption near-edge structure (XANES) for alloys of $\mathrm{Pt}$ with transition metals. The investigation revealed higher Pt 5d-orbital vacancies for the alloys than for the Pt/C catalyst. ${ }^{18}$

At the surface of cycled $\mathrm{Pt}_{75} \mathrm{Co}_{25}$, a binding energy shift of Pt $4 \mathrm{f}_{72}$ to $70.9 \mathrm{eV}$ was obtained, which might suggest that there is no Co left on the surface. The positive shift in the position of $\mathrm{Pt} 4 \mathrm{f}_{7 / 2}$ for to $71.5 \mathrm{eV}$ in the bulk of cycled $\mathrm{Pt}_{75} \mathrm{Co}_{25}$ indicates the interaction of $\mathrm{Pt}$ and $\mathrm{Co}$ in the core of the electrode.

Also, in the case of cycled $\mathrm{Pt}_{10} \mathrm{Co}_{90}$, metallic $\mathrm{Pt}$ is the dominant species at the surface and a measurable platinum-cobalt interaction is measured in the core with $\mathrm{Pt} 4 \mathrm{f}_{7 / 2}$ binding energy of $71.0 \mathrm{eV}$ at the surface and $71.7 \mathrm{eV}$ in the bulk. However, in contrast to $\mathrm{Pt}_{75} \mathrm{CO}_{25}$, both metallic and oxidized cobalt are present on the surface of the $\mathrm{Pt}_{10} \mathrm{CO}_{90}$. On the basis of the XPS depth profile measurements, the electronic interaction among $\mathrm{Pt}$ and Co enhances the stability of $\mathrm{Pt}_{10} \mathrm{CO}_{90}$ even after 1000 potential cycles, thus making it favorable for ORR kinetics.

3.5. Effect of Particle Size on ORR Activity. 3.5.1. Fres $h$ Electrodes. The particle size distribution for freshly prepared and cycled $\mathrm{Pt}, \mathrm{Pt}_{75} \mathrm{CO}_{25}$, and $\mathrm{Pt}_{10} \mathrm{Co}_{90}$ electrodes is given in Figure 15. The particle size and the standard deviation of freshly prepared $\mathrm{Pt}, \mathrm{Pt}_{75} \mathrm{Co}_{25}$, and $\mathrm{Pt}_{10} \mathrm{Co}_{90}$ was found to be $4.5 \pm 1.24,4.7 \pm 1.57$, and $2.9 \pm 1.06 \mathrm{~nm}$, respectively. The particle sizes of $\mathrm{Pt}$ and $\mathrm{Pt}_{75} \mathrm{CO}_{25}$ was found to be similar, but, as discussed earlier, the performance of $\mathrm{Pt}_{75} \mathrm{CO}_{25}$ in the initial stage of potential cycling was far superior when compared to that of pure Pt. At the same time, $\mathrm{Pt}_{10} \mathrm{Co}_{90}$ has a far smaller average particle size than $\mathrm{Pt}_{75} \mathrm{Co}_{25}$, which does not translate into an activity far higher than that of $\mathrm{Pt}_{75} \mathrm{Co}_{25}$. The role of $\mathrm{Co}$ as an alloying element with $\mathrm{Pt}$ to improve ORR kinetics can therefore not be associated with a particle size effect. 

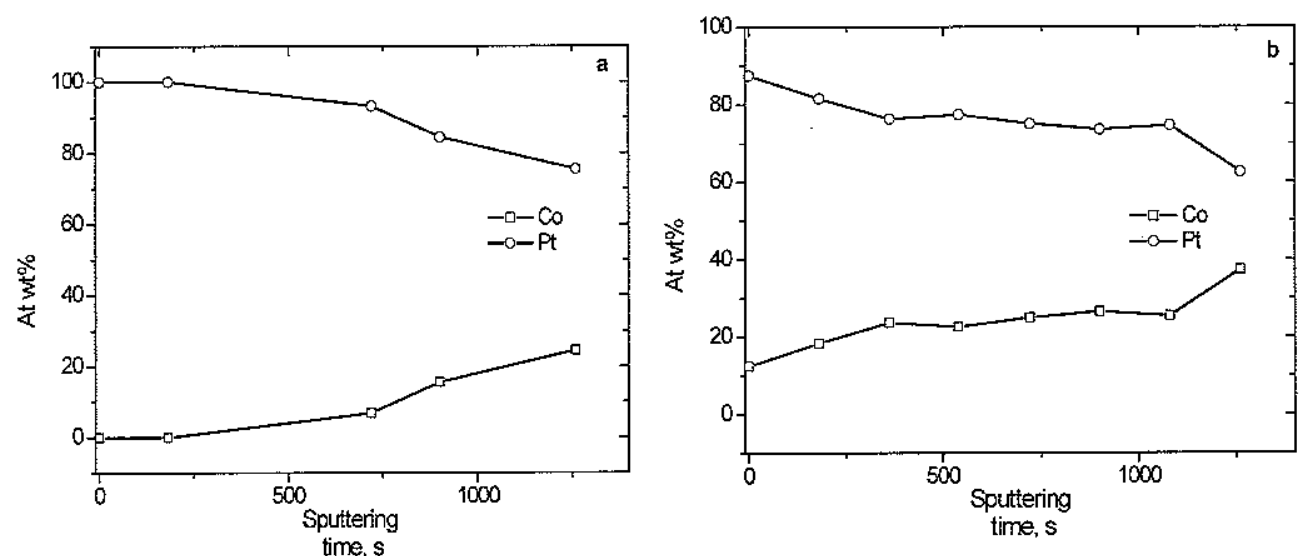

Figure 12. XPS depth profile of (a) $\mathrm{Pt}_{75} \mathrm{Co}_{25}$ and (b) $\mathrm{Pt}_{10} \mathrm{Co}_{90}$ after $1000 \mathrm{CV}$.
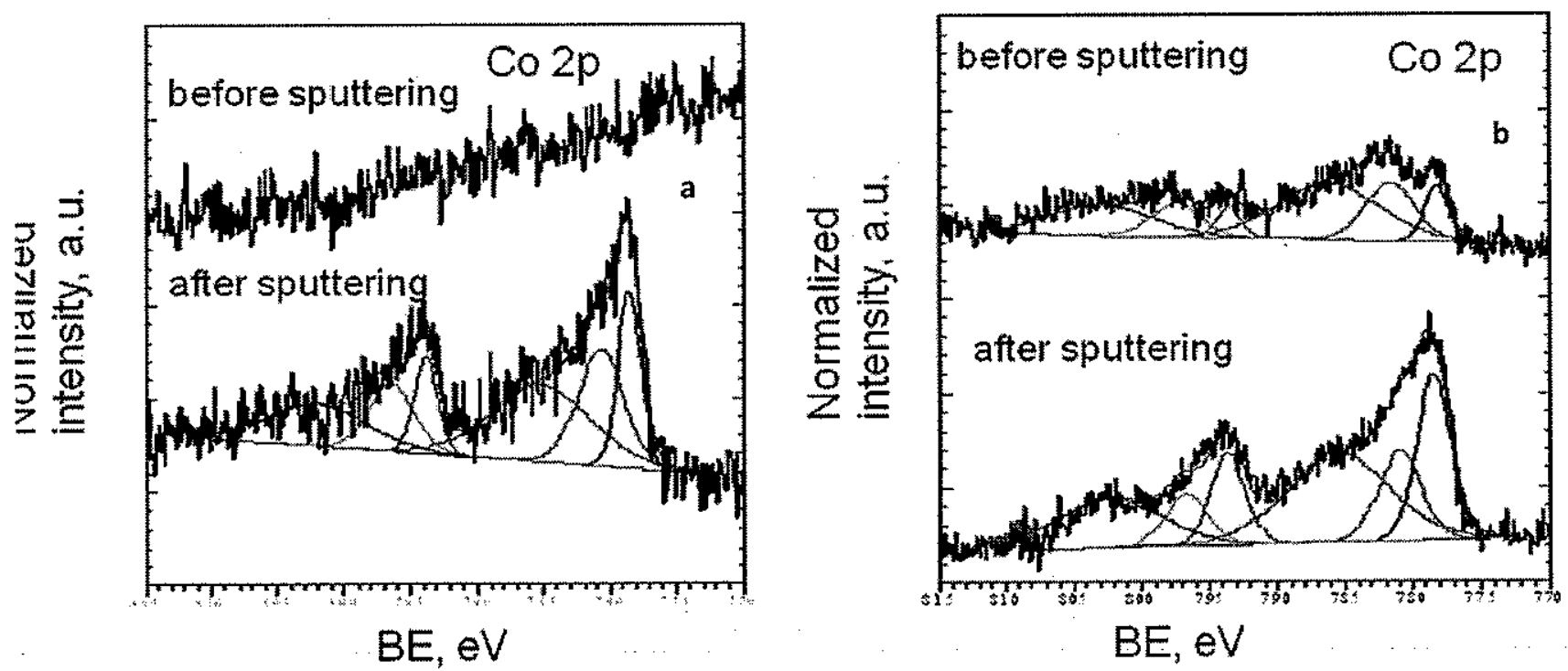

Figure 13. Co 2p XPS spectra before and after sputtering (a) $\mathrm{Pt}_{75} \mathrm{Co}_{25}$ and (b) $\mathrm{Pt}_{10} \mathrm{Co}_{90}$ after $1000 \mathrm{CVs}$.
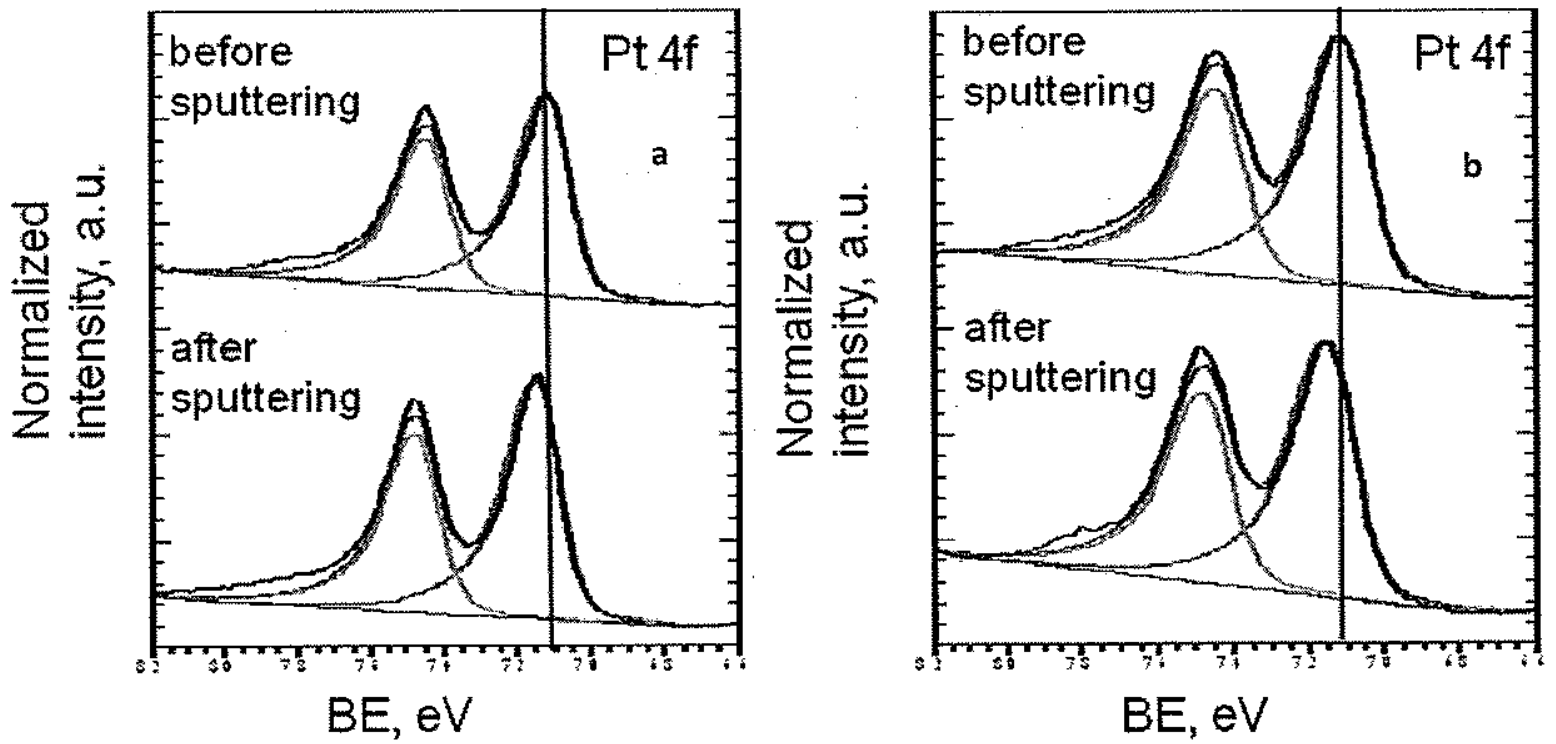

Figure 14. Pt $4 \mathrm{f} X P S$ spectra before and after sputtering (a) $\mathrm{Pt}_{75} \mathrm{Co}_{25}$ and (b) $\mathrm{Pt}_{10} \mathrm{CO}_{90}$ after $1000 \mathrm{CVs}$.

3.5.2. Cycled Electrodes. The particle sizes of $\mathrm{Pt}, \mathrm{Pt}_{75} \mathrm{Co}_{25}$, and $\mathrm{Pt}_{10} \mathrm{Co}_{90}$ become almost similar $(\sim 5 \mathrm{~nm})$ after 1000 potential cycles with a standard deviation of $\sim 2.2 \mathrm{~nm}$. The particle size analysis show a broad distribution of 2-15 $\mathrm{nm}$ for cycled catalysts, a substantial increase from the $2-9 \mathrm{~nm}$ of the fresh catalysts. However, upon comparing the ORR activity, the 
TABLE 1: XPS Binding Energies for $\mathrm{Pt}_{75} \mathrm{Co}_{25}$ and $\mathrm{Pt}_{10} \mathrm{Co}_{90}$ before and after Potential Cycling

\begin{tabular}{|c|c|c|c|c|c|c|c|c|c|c|}
\hline \multirow[b]{3}{*}{ electrode } & \multirow{2}{*}{\multicolumn{2}{|c|}{ EDS }} & \multirow{2}{*}{\multicolumn{2}{|c|}{ XPS }} & \multirow{2}{*}{\multicolumn{2}{|c|}{$\mathrm{BE} \mathrm{Pt} 4 \mathrm{f}_{7 / 2}$}} & \multicolumn{4}{|c|}{$\mathrm{BE} \mathrm{Co} 2 \mathrm{p}_{3 / 2}$} \\
\hline & & & & & & & \multicolumn{2}{|c|}{ before sputtering } & \multicolumn{2}{|c|}{ after sputtering } \\
\hline & at $\% \mathrm{Pt}$ & at $\% \mathrm{Co}$ & at $\% \mathrm{Pt}$ & $\mathrm{at} \% \mathrm{Co}$ & before sputtering & after sputtering & metal & oxides & metal & oxides \\
\hline $\mathrm{Pt}_{75} \mathrm{Co}_{25}$ fresh & 73 & 27 & 74 & 26 & 71.1 & 71.3 & 778.1 & 780.9 & 778.4 & 780.4 \\
\hline $\mathrm{Pt}_{75} \mathrm{Co}_{25} 1000 \mathrm{CVs}$ & 98 & 2 & 91 & 9 & 71.1 & 71.4 & & & 778.5 & 780.7 \\
\hline $\mathrm{Pt}_{10} \mathrm{CO}_{90}$ fresh & 9 & 91 & 11 & 91 & 71.8 & 71.8 & 778.4 & 780.1 & 778.4 & 780.2 \\
\hline $\begin{array}{l}\mathrm{Pt}_{10} \mathrm{C} 0_{90} 1000 \mathrm{CVs} \\
\text { pure Pt foil }\end{array}$ & 85 & 15 & 83 & 17 & 71.1 & 71.6 & 778.4 & 781.7 & 778.8 & 781.9 \\
\hline
\end{tabular}

performance of $\mathrm{Pt}_{10} \mathrm{Co}_{90}$ is far better than that of $\mathrm{Pt}$ and $\mathrm{Pt}_{75} \mathrm{Co}_{25}$. Thus, the enhanced activity and stability of $\mathrm{Pt}_{10} \mathrm{Co}_{90}$ seems more related to the presence of Co (Figure 13) on the surface of the electrode after 1000 potential cycles, rather than on a difference in particle size.

3.6. Reproducibility. In order to study the reproducibility of the electrodes, all the experiments were repeated in terms of catalyst preparation, ORR activity, and the stability. $\mathrm{Pt}_{75} \mathrm{Co}_{25}$ and $\mathrm{Pt}_{10} \mathrm{CO}_{90}$ were prepared and tested at least three times, and all the other catalysts were tested twice. Figure S3 (see
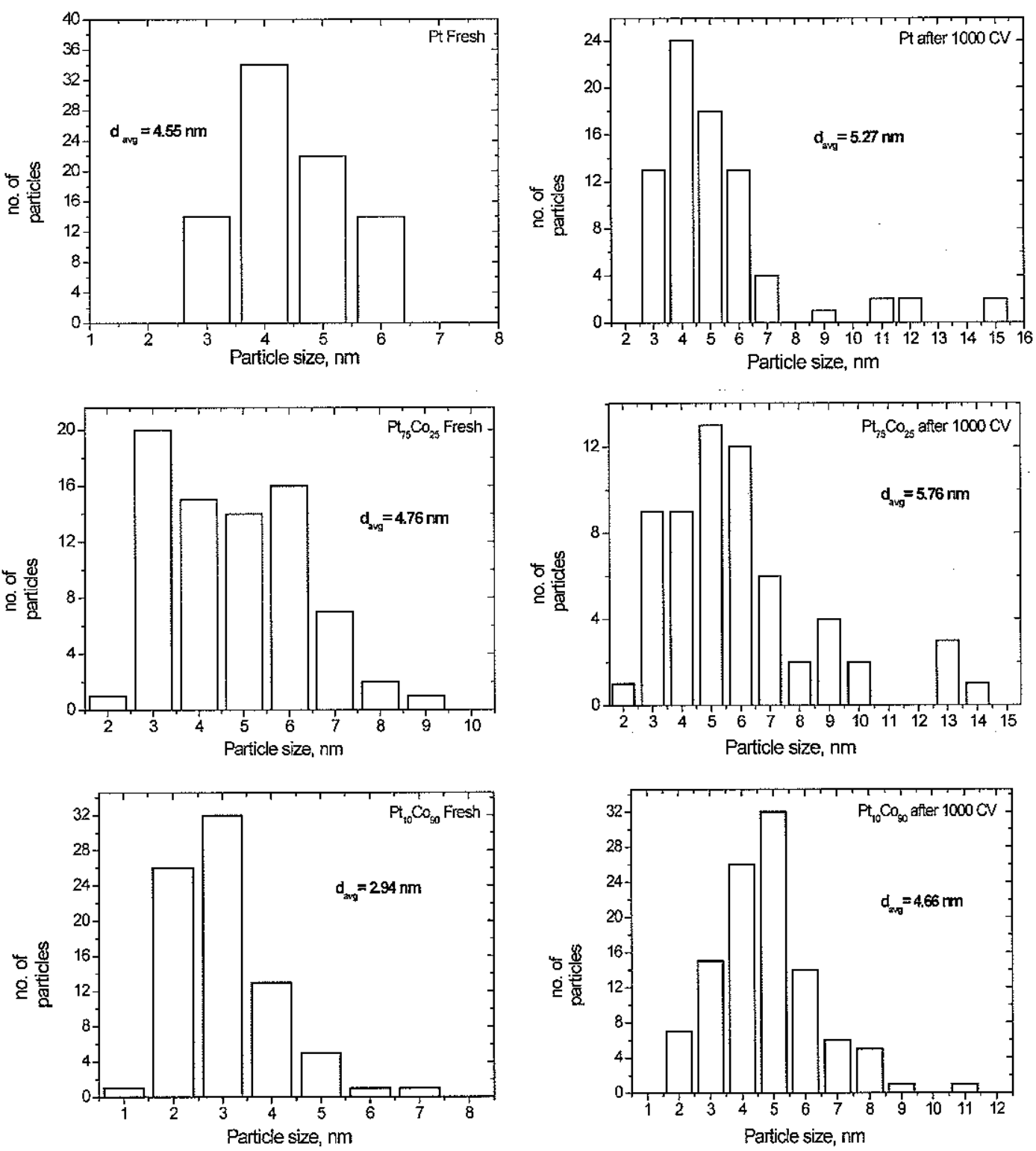

Supporting Information) shows the ORR activity of $\mathrm{Pt}_{75} \mathrm{CO}_{25}$ and $\mathrm{Pt}_{10} \mathrm{Co}_{90}$ measured after 1000 potential cycles. The terms $\mathrm{S} 1, \mathrm{~S} 2, \mathrm{~S} 3$, and S4 represents the number of samples considered. It was found that the catalysts are highly reproducible with similar activities throughout the stability studies. The maximum deviation in the ORR potential of different samples with the same Pt:Co composition at any current is approximately \pm 25 $\mathrm{mV}$, and is much smaller than the variation of the ORR between , various compositions, i.e., the measured effects are significant.

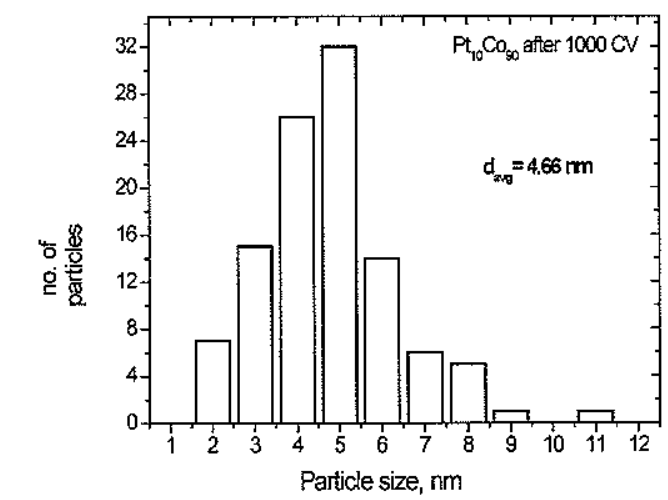

Figure 15. Particle size histograms of $\mathrm{Pt}$ and PtCo alloys, before and after $1000 \mathrm{CVs}$. 
TABLE 2: Comparison of active Pt Surface Area, Half-Wave Potential $E_{1 / 2}$, and Elemental Composition of Pt and PtCo Alloys in Intervals of 1, 15, 65, and 1000 Potential Cycles

\begin{tabular}{|c|c|c|c|c|c|c|c|c|c|c|c|c|}
\hline \multirow[b]{2}{*}{ parameters } & \multicolumn{4}{|c|}{$\mathrm{Pt}$} & \multicolumn{4}{|c|}{$\mathrm{Pt}_{80} \mathrm{Co}_{20}$} & \multicolumn{4}{|c|}{$\mathrm{PL}_{75} \mathrm{Co}_{25}$} \\
\hline & F & 15 & 65 & 1000 & $\mathrm{~F}$ & 15 & 65 & 1000 & F & 15 & 65 & 1000 \\
\hline $\begin{array}{l}\text { real surface } \\
\text { arca, } \mathrm{cm}^{2}\end{array}$ & 16.7 & 10.8 & 6.2 & 5.4 & 20 & 14.5 & 6.0 & 4.2 & 22.5 & 15.1 & 6.3 & 4.2 \\
\hline $\begin{array}{l}\text { Co atom \% } \\
\text { half-wave } \\
\text { potential } E_{l / 2,}, \mathrm{mV}\end{array}$ & $760 \pm 20$ & $770 \pm 20$ & $725 \pm 25$ & $625 \pm 20$ & $\begin{array}{l}19 \\
900 \pm 20\end{array}$ & $\begin{array}{l}10 \\
900 \pm 20\end{array}$ & $\begin{array}{l}6 \\
835 \pm 20\end{array}$ & $\frac{2}{680 \pm 20}$ & $\begin{array}{l}27 \\
900 \pm 20\end{array}$ & $\begin{array}{l}19 \\
900 \pm 20\end{array}$ & $\begin{array}{l}11 \\
860 \pm 20\end{array}$ & $685 \pm 15$ \\
\hline $\begin{array}{l}\text { I } 900 \mathrm{mV} \\
\mathrm{uA} / \mathrm{cm}^{2}\end{array}$ & 2.4 & 3.6 & 5.4 & 0.3 & 40.8 & 56.3 & 15.2 & 1.3 & 49.7 & 74.2 & 51.7 & 1.13 \\
\hline \multirow{2}{*}{$\begin{array}{l}\text { Performancc } \\
\text { loss }{ }^{\star}, \mathrm{mV}\end{array}$} & \multicolumn{4}{|c|}{$140 \pm 25$} & \multicolumn{4}{|c|}{$220 \pm 20$} & \multicolumn{4}{|c|}{$220 \pm 20$} \\
\hline & \multicolumn{4}{|c|}{$\mathrm{Pt}_{60} \mathrm{Co}_{40}$} & \multicolumn{4}{|c|}{$\mathrm{Pt}_{30} \mathrm{CO}_{70}$} & \multicolumn{4}{|c|}{$\mathrm{Pt}_{10} \mathrm{Co}_{90}$} \\
\hline parameters & F & 15 & 65 & 1000 & F & 15 & 65 & 1000 & F & 15 & 65 & 1000 \\
\hline $\begin{array}{l}\text { real surface } \\
\text { arca, } \mathrm{cm}^{2}\end{array}$ & 22.9 & 15.1 & 7.4 & 4.4 & 19.1 & 14.9 & 8.2 & 5.2 & 28 & 16.2 & 8.7 & 5.1 \\
\hline Co atom $\%$ & 42 & 28 & 17 & 6 & 72 & 47 & 31 & 8 & 89 & 60 & 42 & 15 \\
\hline $\begin{array}{l}\text { half-wave } \\
\text { potential } E_{1 / 2}, \mathrm{mV}\end{array}$ & $820 \pm 15$ & $840 \pm 15$ & $805 \pm 20$ & $735 \pm 15$ & $800 \pm 20$ & $810 \pm 20$ & $795 \pm 15$ & $700 \pm 20$ & $920 \pm 20$ & $915 \pm 20$ & $885 \pm 20$ & $840 \pm 25$ \\
\hline $\begin{array}{l}\mathrm{I} @ 900 \mathrm{mV}, \\
\mathrm{uA} / \mathrm{cm}^{2}\end{array}$ & 6.2 & 10.9 & 9.5 & 2.7 & 3.2 & 3.1 & 10.1 & 1.9 & 42.9 & 74 & 79.5 & 31.8 \\
\hline $\begin{array}{l}\text { Performance } \\
\text { loss }{ }^{\star}, \mathrm{mV}\end{array}$ & \multicolumn{4}{|c|}{$110 \pm 20$} & \multicolumn{4}{|c|}{$100 \pm 20$} & \multicolumn{4}{|c|}{$75 \pm 25$} \\
\hline
\end{tabular}

${ }^{a}$ Difference in ORR potential @ $\mathrm{E}_{1 / 2}$ betwecn cycle 1 and 1000; F - Fresh clectrode.

3.7. Effect of Co Dissolution to Use in Fuel Cells. Leaching of Co from the cathode catalyst layer during the operation of the fuel cell can lead to the diffusion of Co into the electrolyte membrane and also to the anode side of the membrane electrode assembly (MEA). ${ }^{3,23,29}$ The exchange of protons by cobalt ions will result in an increase of membrane resistance, while deposition of $\mathrm{Co}$ on the anode will lead to a decrease in hydrogen oxidation activity.

The present work shows the rapid dissolution of Co from the alloy catalysts during initial potential cycles. To prevent the detrimental effects of dissolved cobalt on membrane and anode, preleaching of $\mathrm{Co}$ from the catalyst before incorporating them into the fuel cell electrode seems mandatory. Preleaching can be performed by treating the bimetallic catalyst in aqueous acid solution as reported by Gasteiger et al., who noticed a very sharp decrease in the dissolution of Co from a multiple preleached $\mathrm{PtCo} / \mathrm{C}$ catalyst compared to a fresh unleached one. ${ }^{3}$ The pretreatment of the catalyst was carried out with $0.5 \mathrm{M}$ $\mathrm{H}_{2} \mathrm{SO}_{4}$ at $90{ }^{\circ} \mathrm{C}$. Lee et al. pretreated his Pt shell-Co core catalyst with $20 \% \mathrm{H}_{2} \mathrm{SO}_{4}$ and observed a significant decrease in the Co dissolution and a higher ORR activity. ${ }^{13}$ Ball et al. preleached their carbon supported PtCo alloys in $0.5 \mathrm{M} \mathrm{H}_{2} \mathrm{SO}_{4}$ at $90{ }^{\circ} \mathrm{C}$ for $24 \mathrm{~h}$ before making the MEA and found that preleached catalysts lost their activity compared to their unleached analogues. ${ }^{29}$

The present work shows that high Co loading catalyst might be preleached while still offering a large performance gain compared to Pt.

\section{Summary and Conclusions}

An overview of the measured elemental composition, surface area, and oxygen reduction activity for all samples is given in Table 2. It shows that $\mathrm{PtCo}$ alloys with widely varying composition show a widely varying activity and stability for oxygen reduction. Platinum-rich alloys show a high initial activity, but lose a large part of this enhanced activity when exposed to potential cycling. The loss of cobalt from the top layers of the catalysts is likely to be the cause of this loss in activity.
$\mathrm{Pt}_{10} \mathrm{CO}_{90}$ electrodes showed superior activity and stability compared to all other compositions. In contrast to platinumrich alloys, Co is still present in this electrode even after 1000 potential cycles. As the particle size as well as the platinum surface area did not vary significantly among different compositions, the likely explanation of the enhanced activity is the change in electronic structure as long as Co is present on the surface or subsurface of the catalyst. XPS data suggest a clear positive shift in the binding energy of platinum when cobalt is present in sufficient amounts.

Acknowledgment. This work was part of the Dutch EOSLT Consortium PEMFC, Contract Nos. EOSLT 06005 and EOSLT 07005 , supported by the Ministry of Economic Affairs.

Supporting Information Available: XPS binding energy of $\mathrm{Pt}_{3} \mathrm{Co}$ during depth profile, CVs of catalysts after 15 cycles, RDE graphs showing the reproducibility and TEM images. This material is available free of charge via the Internet at http:// pubs.acs.org.

\section{References and Notes}

(1) Vielstich, W.; Lamm, A.; Gasteiger, H. A. Handbook of Fuel Cells, Fundamentals Technology and Applications; John Wiley \& Sons, Ltd.: Chichester, England, 2003.

(2) de Bruijn, F. A.; Dam, V. A. T.; Janssen, G. J. M. Durability and degradation issues of PEM fuel cell components. Fuel Cells 2008, 8 (1), 3-22.

(3) Gasteiger, H. A.; Kocha, S. S.; Sompalli, B.; Wagner, F. T. Activity benchmarks and requirements for $\mathrm{Pt}$, Pt-alloy, and non-Pt oxygen reduction catalysts for PEMFCs. Appl. Catal., B 2005, 56 (1-2), 9-35.

(4) Mukerjee, S.; Srinivasan, S. Enhanced electrocatalysis of oxygen reduction on platinum alloys in proton-exchange membrane fuel-cells. $J$ Electroanal. Chem. 1993, 357 (1-2), 201-224.

(5) Stamenkovic, V.; Schmidt, T. J.; Ross, P. N.; Markovic, N. M. Surface composition effects in electrocatalysis: Kinetics of oxygen reduction on well-defined $\mathrm{Pt}_{3} \mathrm{Ni}$ and $\mathrm{Pt}_{3} \mathrm{Co}$ alloy surfaces. J. Phys. Chem. $B$ 2002, 106 (46), $11970-11979$.

(6) Stamenkovic, V. R.; Mun, B. S.; Arenz, M.; Maymofer, K. J. J.; Lucas, C. A.; Wang, G. F.; Ross, P. N.; Markovic, N. M. Trends in electrocatalysis on extended and nanoscale Pt-bimetallic alloy surfaces. Nat. Mater. 2007, 6 (3), 241-247. 
(7) Toda, T.; Igarashi, H.; Watanabe, M. Enhancement of the electrocatalytic $\mathrm{O}-2$ reduction on $\mathrm{Pt}-\mathrm{Fe}$ alloys. J. Electroanal. Chem. 1999, 460 $(1-2), 258-262$.

(8) Mukerjee, S.; Srinivasan, S.; Soriaga, M. P.; Mcbreen, J. Role of structural and electronic-properties of Pt and Pt alloys on electrocatalysis of oxygen reduction - An in-situ XANES and EXAFS investigation. $J$. Electrochem. Soc. 1995, l42 (5), 1409-1422.

(9) Paulus, U. A.; Wokaun, A.; Scherer, G G; Schmidt, T. J. Stamenkovic, V.; Radmilovic, V.; Markovic, N. M.; Ross, P. N. Oxygen reduction on carbon-supported $\mathrm{Pt}-\mathrm{Ni}$ and $\mathrm{Pt}-\mathrm{Co}$ alloy catalysts. J. Phys. Chem. B 2002, $106(16), 4181-4191$.

(10) Paulus, U. A.; Wokaun, A.; Scherer, G. G.; Schmidt, T. J Stamenkovic, V.; Markovic, N. M.; Ross, P. N. Oxygen reduction on high surface area Pt-based alloy catalysts in comparison to well defined smooth bulk alloy electrodes. Electrochim. Acta 2002, 47 (22-23), 3787-3798.

(11) Travitsky, N.; Ripenbein, T.; Golodnitsky, D.; Rosenberg, Y. Burshtein, L.; Peled, E. Pt-, PtNi- and PtCo-supported catalysts for oxygen reduction in PEM fuel cells. J. Power Sources 2006, I6l (2), 782-789.

(12) Watanabe, M.; Tsurumi, K.; Mizukami, T.; Nakamura, T.; Stonehart, P. Activity and stability of ordered and disordered $\mathrm{Co}-\mathrm{Pt}$ alloys for phosphoric-acid fuel-cells. J. Electrochem. Soc. 1994, 141 (10), 2659-2668.

(13) Lee, M. H.; Wang, P. S.; Do, J. S. Effect of acid treatment of Corich core-Pt-rich shell/C electrocatalyst on oxygen reduction reaction. $J$ Solid State Electrochem. 2008, I2 (7-8), 879-884.

(14) Srivastava, R.; Mani, P.; Hahn, N.; Strasser, P. Efficient oxygen reduction fuel cell electrocatalysis on voltammetrically dealloyed $\mathrm{Pt}-\mathrm{Cu}-$ Co nanoparticles. Angew. Chem., Int. Ed. 2007, 46 (47), 8988-8991.

(15) Stamenkovic, V. R.; Fowler, B.; Mun, B. S.; Wang, G. F.; Ross, P. N.; Lucas, C. A.; Markovic, N. M. Improved oxygen reduction activity on $\mathrm{P}_{3} \mathrm{Ni}(111)$ via increased surface site availability. Science 2007,315 (5811), 493-497.

(16) Adzic, R. R.; Zhang I.; Sasaki, K.; Vukmirovic, M. B.; Shao, M. Wang, J. X.; Nilekar, A. U.; Mavrikakis, M.; Valerio, J. A.; Uribe, F. Platinum monolayer fuel cell electrocatalysts. Top. Catal. 2007, 46 (3-4), 249-262.

(17) Saejeng, Y.; Tantavichet, N. Preparation of Pt-Co alloy catalysts by electrodeposition for oxygen reduction in PEMFC. J. Appl. Electrochem. $2009,39(1), 123-134$

(18) Mukerjee, S.; Mcbreen, J. Effect of particle size on the electrocatalysis by carbon-supported Pt electrocatalysts: An in situ XAS investigation. J. Electroanal. Chem. 1998, 448 (2), 163-171.
(19) Markovic, N.; Gasteiger, H.; Ross, P. N. Kinetics of oxygen reduction on $\mathrm{Pt}(h k l)$ electrodes: Implications for the crystallite size effect with supported Pt electrocatalysts. J. Electrochem. Soc. 1997, 144 (5), 15911597.

(20) Mallett, J. J.; Svedberg, E. B.; Sayan, S.; Shapiro, A. J.; Wielunski, L.; Madey, T. E.; Chen, P. J.; Egelhoff, W. F.; Moffat, T. P. Compositional control in electrodeposited $\mathrm{Co}_{x} \mathrm{Pt}_{1-x}$ films. Electrochem. Solid State Lett. 2005, 8 (1), C15-C18.

(21) Kinoshita, K. Electrochemical Oxygen Technology; Wiley; New York, 1992.

(22) Koh, S.; Toney, M. F.; Strasser, P. Activity-stability relationships of ordered and disordered alloy phases of $\mathrm{Pt}_{3} \mathrm{Co}$ electrocatalysts for the oxygen reduction reaction (ORR). Electrochim. Acta 2007, 52 (8), 27652774

(23) Colon-Mercado, H. R.; Popov, B. N. Stability of platinum based alloy cathode catalysts in PEM fuel cells. J. Power Sources 2006, 155 (2), 253-263.

(24) Koh, S.; Strasser, P. Electrocatalysis on bimetallic surfaces: Modifying catalytic reactivity for oxygen reduction by voltammetric surface dealloying. J. Am. Chem. Soc. 2007, 129 (42), 12624.

(25) Strasser, P.; Koha, S.; Greeley, J. Voltammetric surface dealloying of Pt bimetallic nanoparticles: an experimental and DFT computational analysis. Phys. Chem. Chem. Phys. 2008, 10 (25), 3670-3683.

(26) Wakisaka, M.; Mitsui, S.; Hirose, Y.; Kawashima, K.; Uchida, H.; Watanabe, M. Electronic structures of $\mathrm{Pt}-\mathrm{Co}$ and $\mathrm{Pt}-\mathrm{Ru}$ alloys for $\mathrm{Co}-$ tolerant anode catalysts in polymer electrolyte fuel cells studied by ECXPS. J. Phys. Chem. B 2006, 110 (46), 23489-23496.

(27) Toda, T.; Igarashi, H.; Uchida, H.; Watanabe, M. Enhancement of the electroreduction of oxygen on $\mathrm{Pt}$ alloys with $\mathrm{Fe}, \mathrm{Ni}$, and $\mathrm{Co} . J$ Electrochem. Soc. 1999, 146 (10), 3750-3756.

(28) Duong, H. T.; Rigsby, M. A.; Zhou, W. P.; Wieckowski, A. Oxygen reduction catalysis of the $\mathrm{Pt} 3 \mathrm{Co}$ alloy in alkaline and acidic media studied by X-ray photoelectron spectroscopy and electrochemical methods. J. Phys. Chem. C 2007, HI (36), 13460-13465.

(29) Ball, S. C.; Hudson, S. L.; Theobald, B.; Thompsett, D. PtCo, a durable catalyst for automotive proton electrolyte metrbrane fuel cells. ECS Trans. 2007, $11(1), 1267-1278$.

JP904762E 